\title{
ANALISIS YURIDIS PENGATURAN PEMBAGIAN WILAYAH ZEE DAN LANDAS KONTINEN DI SELAT MALAKA MENURUT UNITED NATION CONVENTION ON THE LAW OF (UNCLOS) 1982 DAN HUKUM NASIONAL
}

\author{
Ahmad Iffan', Raihana ${ }^{2}$, Asrizal $^{3}$
}

\begin{abstract}
ABSTRAK
Penelitian ini bertujuan untuk mengetahui pengaturan internasional dan nasional mengenai pembagian landas kontinen dan wilayah ZEE di selat malaka dan perjanjian negara indonesia dan malaysia dalam pembagian wilayah ZEE dan landas kontinen di Selat Malaka. Adapun tujuan dari penelitian ini adalah sebagai berikut: Pertama, pengaturan Internasional dan Nasional mengenai pembagian landas kontinen dan wilayah ZEE di selat Malaka; Kedua, perjanjian negara Indonesia dan Malaysia terkait pembagian wilayah ZEE dan landas kontinen di selat Malaka. Metode penelitian yang digunakan adalah penelitian yuridis normatif dengan penelitian ini adalah deskriptif yaitu penelitian yang bertujuan untuk mengetahui analisis dan pengaturan United Nation Convention On The Law Of Sea (UNCLOS) 1982, Hukum Nasional Republik Indonesia dan juga kerjasama antar negara yang berbatasan dengan selat malaka dalam pengaturan pembagian wilayah ZEE dan landas kontinen di selat malaka dan sumber data yang digunakan adalah data sekunder yaitu datadata yang diperoleh dari bahan-bahan perpustakaan seperti buku-buku, jurnal, artikel dan informasi dari website atau data yang diperoleh oleh peneliti secara tidak langsung dari objeknya tetapi dari sumber lain baik lisan maupun tulisan. Hasil penelitian ini adalah diketahui adanya pengukuran awal landas kontinen yang disepakati merugikan Indonesia dari sudut pandang pengukuran yang di tarik dari garis pangkal dan juga hasil penelitian ini menunjukkan adanya perjanjian mengenai batas landas kontinen di selat malaka antara Indonesia dan Malaysia yang sudah sangat lama dan perlu dilakukan perbaharuan sesuai dengan perkembangan zaman. dan fakta menunjukkan bahwa negara Indonesia belum pernah melakukan hubungan bilateral ataupun perjanjian terkait batas ZEO di selat malaka antara negara Malaysia dan Indonesia.
\end{abstract}

\section{Kata kunci: Landas Kontinen; Zona Ekonomi Ekslusif (ZEE); Selat Malaka.}

\section{ABSTRACT}

This study aims to determine the international and national arrangements regarding the division of the continental shelf and the ZEE region in the Malacca Strait and the agreement between Indonesia and Malaysia in the division of the EEZ region and the continental shelf in the Malacca Strait. The objectives of this study are as follows: First, International and National arrangements regarding the division of continental shelf and EEZ region in the Malacca Strait; Second, the agreement between Indonesia and Malaysia regarding the division of EEZ areas and the continental shelf in the Malacca Strait. The research method used is normative juridical research with this research is descriptive research that aims to determine the analysis and regulation of the United Nations Convention On The Law Of Sea (UNCLOS) 1982, National Law of the Republic of Indonesia and also cooperation between countries bordering the Malacca Strait in regulating the division of zee territories and continental shelf in the Malacca Strait and the data sources used are secondary data that is

\footnotetext{
${ }^{1}$ Dosen Program Studi IImu Hukum, Fakultas Hukum Universitas Bung Hatta Padang, Email: a.jurist08@gmail.com

${ }^{2}$ Dosen Program Studi Ilmu Hukum, Fakultas Hukum Universitas Muhammadiyah Riau, Email: raihana.nasution@gmail.com

${ }^{3}$ Dosen Program Studi Hukum Ekonomi Syariah, Sekolah Tinggi Agama Islam Negeri Sultan Abdurrahman Kepulauan Riau, email: asrizalsaiin@gmail.com
} 
data obtained from library materials such as books, journals, articles and information from websites or data obtained by researchers indirectly from the object but from other sources both oral and written. The results of this study are known to have an initial measurement of the continental shelf that was agreed to harm Indonesia from the point of view of measurements drawn from the baseline and also the results of this study indicate an agreement on the continental shelf boundary in the Malacca Strait between Indonesia and Malaysia which is very long and needs to be done renewal in accordance with the times. and the facts show that the Indonesian state has never had bilateral relations or ZEE boundary agreements in the Malacca Strait between Malaysia and Indonesia.

Keywords: Continental Platform; Exclusive Economic Zone; Malacca Strait.

\section{PENDAHULUAN}

\subsection{Latar Belakang}

Indonesia memiliki wilayah yang sangat luas, terbentang dari sabang sampai merauke. Wilayah geografis yang sangat strategis dalam melakukan perniagaan dengan negara-negara asing, letak strategis ini dapat dilihat dari posisi Indonesia yang berada dijalur khatulistiwa. Negara Kesatuan Republik Indonesia (NKRI) mempunyai kewajiban untuk menjaga kedaulatannya dari berbagai aspek kehidupan bernegara baik berasal dari luar maupun dari dalam. Dengan luasnya laut yang mengelilingi wilayah Indonesia maka wajib Indonesia mempunyai regulasi peraturan mengenai ketentuan-ketentuan wilayah lautnya baik itu laut teritorial, zona tambahan, zona ekonomi ekslusif, landas kontinen dan laut bebas.

Negara Kesatuan Republik Indonesia merupakan negara dengan wilayah perairan terbesar di dunia dan dua pertiga dari wilayahnya merupakan wilayah perairan. Secara geografis Indonesia merupakan negara maritim, yang memiliki luas laut sebesar 5.8 juta $\mathrm{Km}^{2}$ yang terdiri dari laut territorial dengan luas 0.8 juta $\mathrm{Km}^{2}$, laut nusantara 2.3 juta $\mathrm{Km}^{2}$ dan zona ekonomi eksklusif 2.7 juta $\mathrm{Km}^{2}$. Disamping itu Indonesia memiliki pulau sebanyak 17.480 pulau dan garis pantai sepanjang $95.181 \mathrm{~km}$. Pada saat Indonesia diproklamasikan sebagai negara yang merdeka pada tanggal 17 Agustus 1945 oleh dwi-tunggal SoekarnoHatta, dan diberlakukan Undang-Undang Dasar 1945 yang resmi pada tanggal 18 Agustus 1945 menyatakan bahwa Indonesia adalah negara kesatuan dalam bentuk Republik, namun sayangnya ketika itu tidak disebutkan batas-batas wilayah nasional Indonesia sesungguhnya. Semenjak saat itu penentuan batas-batas wilayah negara Republik Indonesia khususnya wilayah laut mengacu pada Ordonansi Hindia Belanda Staatsblad 1939 Nomor 442, yaitu 
Territoriale Zee ën Maritieme Kringen Ordonnantie 1939 (TZMKO 1939/ Ordonansi Laut Teritorial dan Lingkungan-lingkungan Maritim 1939). ${ }^{4}$

Indonesia adalah salah satu negara di dunia yang perbatasannya dengan negara tetangga dibatasi oleh laut, dan negara-negara tetangga itu seperti Malaysia, Singapura, Brunai Darussalam, Filipina, Thailand, Timor-Timor dan negara lainnya. Maka oleh karena itu Indonesia sangat sering berkonflik dengan negara-negara tetangga mengenai penetapan batas wilayah perbatasan di laut. Salah satu yang menjadi perhatian khusus adalah wilayah laut di selat malaka yang luasnya tidak sampai dari 24 Mil perwilayah negara apabila dibagi dengan mengambil jalan tengah diukur dari garing pangkal. Dalam mengatur wilayah berbatasan laut di selat malaka perlu regulasi khusus yang dibuat oleh Indonesia dengan Malaysia mulai dari menentukan wilayah ZEE dan landas kontinen setiap negara. Selat malaka merupakan salah satu selat yang strategis di dunia, berbagai kapal melewati wilayah tersebut guna melancarkan perniagaan yang mereka lakukan, hampir seluruh negara di dunia akan melewati wilayah selat malaka ketika akan melewati jalur asia ke bagian dunia lainnya. Selat malaka tidak hanya sebagai selat yang sangat strategis tetai juga memiliki sumber daya alam (SDA) yang sangat melimpah di dasar lautnya, hal inilah yang menjadi salah satu sumber terjadinya konflik antara Indonesia dan Malaysia mengenai penetapan wilayah ZEE dan landas kontinen di Selat Malaka.

Undang-Undang Dasar (UUD) Republik Indonesia 1945 mengatur mengenai kewajiban negara untuk mempertahankan kedaulalatan negara. Terdapat di dalam Pasal 30 ayat 3 UUD 1945 yang berbunyi "Tentara Nasional Indonesia terdiri atas Angkatan darat, Angkatan Laut, dan Angkatan Udara sebagai alat Negara bertugas mempertahankan, melindungi, dan memelihara keutuhan dan kedaulatan Negara". 5 Negara Indonesia telah memberikan mandat kepada TNI dan Polri sebagai alat kelengkapan negara dalam mempertahankan NKRI, hal ini di sebut dalam Pasal 30 ayat 2 UUD 1945 : "usaha pertahanan dan keamanan negara dilaksanakan melalui sistem pertahanan dan keamanan rakyat semesta oleh Tentara Nasional Indonesia dan Kepolisisan Negara Republik Indonesia, sebagai kekuatan utama, dan rakyat sebagai kekuatan pendukung." 6 TNI dan Polri berkewajiban menjaga keamanan dan kedaulatan wilayah NKRI di darat, laut dan udara.

\footnotetext{
${ }^{4}$ Ansori, "Cara Penetapan Batas Zee Antara Indonesia dan Malaysia Diselat Malaka Dengan Media Line”, Jurnal Perspektif Hukum, Volume 12 Nomor 2 November 2012 : 15-26, hlm.16.

${ }^{5}$ Pasal 30 ayat 3 UUD 1945.

${ }^{6}$ Pasal 30 ayat 2 UUD 1945.
} 
Selat malaka adalah salah satu selat Internasional di Indonesia yang menjadi jalur perlayaran bagi kapal-kapal asing untuk menghubungkan dari wilayah timur ke wilayah bagian barat. Daerah-daerah yang berbatasan dengan Selat Malaka merupakan wilayah keanekaragaman hayati tinggi dan lingkungan yang peka. Keanekaragaman itu terancam melalui pembalakan di hutan-hutan hujan yang masih tersisa di Sumatera dan Semenanjung Malaysia dan kerentanan ekologisnya meningkat, misalnya melalui penyusutan hutan bakau di wilayah pesisir dan melalui ancaman pencemaran minyak. ${ }^{7}$ Selat Malaka menyimpan peluang besar untuk pembangunan ekonomi dan sosial bagi negara-negara di pesisir selat, yaitu Indonesia, Singapura, Malaysia dan Thailand. Selain itu juga dapat menciptakan perdamaian dan stabilitas di wilayah negara pesisir selat merupakan prasyarat bagi pembangunan regional, suplai energi yang berkelanjutan dan perdagangan Internasional misalnya antara lain dengan Uni Eropa dan Asia Timur. ${ }^{8}$

Selat malaka juga mempunyai posisi yang sangat trategis dalam memajukan perekonomian terutama yang bersumber dari laut yang mempunyai kekayaan alam yang melimpah dan juga merupakan alur lewatnya kapal-kapal perniagaan dari seluruh dunia, hal ini dapat dillihat bahwa sekitar 50. 000 kapal yang setiap tahun berlayar, mengangkut sepertiga dari jumlah perdagangan laut di dunia melewati Selat Malaka. Setelah angkutan kargo umum, minyak adalah komoditi terpenting yang diangkut. Karena lebar titik tersempit Selat Malaka hanya sekitar 1,5 Mil nautik $(2,8 \mathrm{~km})$ dan 0,6 Mil nautik (1,1 km), Phillips Channel di Selat Singapura dan kawasan sepanjang the One Fathom Bank merupakan salah satu titik tersempit yang terpenting bagi lalu lintas laut dunia. Setengah dari jumlah keseluruhan angkutan minyak melalui jalan laut, melewati Selat Malaka. Tahun 2003, 19.154 tanker yang mengangkut lebih dari 10 juta barrel per-hari, melayari Selat Malaka ke arah timur (negara-negara Teluk Persia-Asia Timur). ${ }^{9}$

Selat malaka tidak hanya memberikan kekayaan yang melimpah kepada negara pesisir selat tetapi juga memiliki keyaaan di pulau-pulau kecil yang berada di tengah-tengah selat Malaka atau terdapat di dalam bagian ZEE, seperti sumber daya alam berupa minyak dan gas bumi yang notabene memiliki siklus pembaharuan yang membutuhkan waktu cukup panjang, potensi sumber daya alam yang ada di Kepulauan Natuna, pulau yang terletak di bagian paling utara kepulauan yang ada di selat Karimata ini menyimpan cadangan gas alam terbesar

\footnotetext{
${ }^{7}$ Hans-Dieter Evers Dan Solvay Gerke, Perkembangan Dan Peluang Wilayah Selat Malaka, Center For Development Research University Of Bonn, hlm.4.

${ }^{8} \mathrm{lbid}, \mathrm{hlm} .5$.

${ }^{9} \mathrm{lbid}, \mathrm{hlm} .6$.
} 
di kawasan Asia Pasifik dan bahkan di Dunia. Secara scientific kekayaan Natuna dibuktikan oleh kandungan gas alam pada salah satu ladang gas D-Alpha yang terletak $225 \mathrm{~km}$ sebelah utara kepulauan Natuna (di dalam ZEE) yang menyimpan 112.356 .680 barel total cadangan gas alam dengan volume sebesar 222 trillion cubic feet (TCT), dengan 46 TCT gas hidrokarbon yang merupakan salah satu sumber terbesar di Asia yang mana angka tersebut belum termasuk cadangan gas alam di bagian barat kepulauan Natuna. Ditambah dengan cadangan minyak bumi di kepulauan Natuna yang diperkirakan mencapai 14.386 .470 barel. ${ }^{10}$

Dengan besarnya kekayaan alam yang berada di selat malaka maka rentan dapat menimbulkan konflik antar negara pesisir selat yang mengklaim dan memperjuangkan kepentingannya di selat Malaka tersebut. Negara-negara yang berbatasan dengan selat malaka adalah negara Thailand, Malaysia, Singapura dan Indonesia. Setiap negara pasti akan mengklaim dan memperjuangkan setiap wilayah yang dianggap sebagai wilayah kedaulatannya termasuk di wilayah laut. Hal inilah yang menimbulkan konflik antar negara yang berbatasan langsung dengan selat Malaka. Oleh karena itu perlu adanya regulasi peraturan yang jelas dan konkrit mengenai pembagian perbatasan di laut terutama di selat Malaka yang merupakan perlintasan laut kecil di negara-negara besar.

Dengan besarnya sumber kekayaan yang dapat diekploitasi dan eksplorasi di selat Malaka, maka sangat perlu untuk membentuk regulasi peraturan yang dapat melindungi setiap kepentingan negara-negara di pesisir selat dan negara-negara lainnya. Dengan latar belakang di atas maka penulis tertarik untuk mengkaji lebih dalam mengenai pembentukan pengaturan terkait pengaturan ZEE dan landas kontinen di selat malaka dengan judul kajian "Analisis Yuridis Terhadap Pengaturan Pembagian Wilayah Zee Dan Landas Kontinen Di Selat Malaka Menurut United Nation Convention On The Law Of Sea (UNCLOS) 1982 dan Hukum Nasional".

Oleh karena itu, rumusan masalah yang dapat dikaji dalam tulisan ini adalah sebagai berikut:

1. Bagaimanakah pengaturan Internasional dan Nasional mengenai pembagian landas kontinen dan wilayah ZEE di selat Malaka?

2. Bagimanakah perjanjian negara Indonesia dan Malaysia terkait pembagian wilayah ZEE dan landas kontinen di selat Malaka?

\footnotetext{
${ }^{10}$ Annisa Purwatiningsih, "Eksplorasi dan Eksploitasi Pertambangan Minyak dan Gas Bumi di Laut Natuna Bagian Utara Laut Yuridiksi Nasional Untuk Meningkatkan Kesejahteraan Masyarakat di Kepulauan Natuna", Jurnal Reformasi, Volume 2, Nomor 2, Juli- Desember 2012, hMl. 61.
} 
Tujuan daripada penelitian ini adalah untuk mengetahui pengaturan Internasional dan Nasional mengenai pembagian landas kontinen dan wilayah ZEE di selat Malaka. Selain itu juga untuk mengetahui perjanjian negara Indonesia dan Malaysia dalam pembagian wilayah ZEE dan landas kontinen di selat Malaka.

\section{METODE PENELITIAN}

Metode penelitian yang digunakan adalah penelitian yuridis normatif. Penelitian yuridis normatif merupakan penelitian kepustakaan atau studi dokumen, yaitu penelitian yang dilakukan atau ditujukan pada peraturan-peraturan yang tertulis atau penelitian yang didasarkan pada data sekunder. Adapun sifat dari penelitian ini adalah deskriptif yaitu penelitian yang bertujuan untuk mengetahui analisis dan pengaturan United Nation Convention On The Law Of Sea (UNCLOS) 1982, Hukum Nasional Republik Indonesia dan juga kerjasama antar negara yang berbatasan dengan selat malaka dalam pengaturan pembagian wilayah ZEE dan landas kontinen di selat Malaka. Sumber data yang digunakan adalah data sekunder yaitu data-data yang diperoleh dari bahan-bahan perpustakaan seperti buku-buku, jurnal, artikel dan informasi dari website atau data yang diperoleh oleh peneliti secara tidak langsung dari objeknya tetapi dari sumber lain baik lisan maupun tulisan. ${ }^{11}$ Bahan informasi dapat merupakan bahan hukum primer, bahan hukum sekunder dan bahan hukum tertier. ${ }^{12}$

Teknik penelitian pengumpulan data yang digunakan adalah teknik penelitian kepustakaan (library research), ${ }^{13}$ yaitu penelitian untuk memperoleh data dengan membaca buku dan teori yang relevansinya dengan masalah yang akan dibahas pada penulisan ini. ${ }^{14}$ Analisa data yang digunakan dengan melakukan penyusunan terhadap data yang diperoleh untuk mendapatkan suatu kesimpulan dalam menganalisis terhadap penulisan ini, penulis menggunakan analisis kualitatif, yaitu pengelompokan data menurut aspek-aspek yang diteliti, diambil suatu kesimpulan dengan atau tanpa menggunakan angka-angka statistik. ${ }^{15}$

\footnotetext{
${ }^{11}$ Suratman \& Philips Dillah, Metode Penelitian Hukum, ALFABETA, Bandung: 2013, hlm. 51.

12 Sulistyowati Irianto dan Sidharta, Metode Penelitian Hukum: Kontelasi dan Refleksi, Jakarta: Yayasan Pustaka Obor Indonesia, 2011, cet ke-2, hlm. 176

${ }^{13}$ Peter Mahmud Marzuki, Penelitian Hukum , Edisi revisi, Kencana, Jakarta, 2013, hlm.47

${ }^{14}$ Zainuddin Ali, Metode Penelitian Hukum, Jakarta: Sinar Grafika, 2010, hlm. 17

${ }^{15}$ Lihat Lexy J. Moleong, Metodologi Penelitian Kualitatif, Bandung: PT Remaja Rosdakarya, 2007, hlm. 5
} 


\section{HASIL PENELITIAN DAN PEMBAHASAN}

\subsection{Pengaturan Pembagian Landas Kontinen dan Wilayah ZEE di Selat Malaka}

UNCLOS merupakan payung hukum tertinggi dalam menentukan batas landas kontinen di setiap negara, maka negara-negara yang telah meratifikasi UNCLOS disyaratkan agar mengikuti setiap peraturan yang berada di UNCLOS. Menurut Konvensi Perserikatan Bangsa - Bangsa (PBB) tentang Hukum Laut Internasional I Tahun 1958 (UNCLOS I 1958) di Jenewa. Secara lengkap pengertian landas kontinen dalam Ketentuan Pasal 1 UNCLOS I Tahun 1958 tentang Landas Kontinen, yang berbunyi sebagai berikut :

"For the purpose of these articles, the term "continental shelf" is used as refering (a) to the seabed and subsoil of the submarine areas adjacent to the coast but autside the area of the territorial sea, to a depth of 200 metres or beyond that limit, to where the superjecent waters admits of the exploitation of the natural resources of the said areas to seabed and subsoli of similar submarine areas adjacent to the coast of islands".

Definisi dalam Ketentuan Pasal 1 UNCLOS III 1958 tentang Landas Kontinen tersebut menentukan batas landas kontinen, yaitu :

a. Dasar laut dan tanah di bawahnya di luar laut territorial sampai kedalaman $200 \mathrm{~m}$, untuk tujuan eksplorasi dan eksploitasi sumber kekayaan alamnya.

b. Dasar laut dan tanah di bawahnya di luar batas kedalaman $200 \mathrm{~m}$, sampai dimana kemampuan teknologi dapat mengeksplorasi dan mengeksploitasi sumber kekayaan alamnya.

Landas kontinen suatu negara pantai meliputi dasar laut dan tanah di bawahnya dari daerah di bawah permukaan laut yang terletak di luar laut teritorialnya sepanjang kelanjutan alamiah wilayah daratannya hingga pinggiran luar tepi kontinen, atau hingga suatu jarak 200 Mil laut dari garis pangkal darimana lebar laut teritorial diukur, dalam hal pinggiran luar tepi kontinen tidak mencapai jarak tersebut.

"For the purpose if these articles, the term continental shelf is used as referring (a) to the seabed and subsoil of the submarine areas adjacent to the coast but outside the area of the territorial sea, to a depth of 200 metres or, beyond that limit, to where the superjacent waters admits of the exploitation of the natural resources of the said areas; (b) to the seabed and subsoil of similar submarine areas adjacent to the coasts of islands".

Titik tetap yang merupakan garis batas luar landas kontinen pada dasar laut, yang di tarik sesuai dengan ayat 4 (a) (i) dan (ii), atau tidak boleh melebihi 350 Mil laut dari garis 
pangkal dimana laut territorial diukur atau tidak boleh melebihi 100 Mil laut dari garis batas kedalaman 2.500 Meter, yaitu suatu garis yang menghubugan kedalaman 2.500 Meter.

UNCLOS 1982 memberikan pengertian mengenai batas landas kontinen yang terdapat Pasal 76 ayat (1) yang berbunyi:

"The continental shelf of a coastal state comprises the sea-bed and subsoil of the submarine areas that extend beyond it's teritorial sea throughout the natural prolongation of its land territory to the outer edge of the coninentl margin, or to a distance of 200 nautical miles from the baselines from which the breadth of the territorial sea is measuredwhere the outer edge of the continental margin does not extend up to that distance".

Landas kontinen suatu Negara pantai meliputi dasar laut dan tanah dibawahnya dari daerah di bawah permukaan laut yang terletak di luar laut teritorialnya sepanjang kelanjutan alamiah wilayah daratannya hingga pinggiran luar tepi kontinen, atau hingga suatu jarak 200 mil laut dari garis pangkal darimana lebar laut teritorial diukur, dalam hal pinggiran luar tepi kontinen tidak mencapai jarak tersebut.

Jika dibandingkan dengan ketentuan Konvensi Hukum Laut 1982, perumusan yang terdapat dalam Pasal 76 Konvensi Hukum Laut 1982 tersebut di atas memberikan batasanbatasan yang lebih jelas dengan memberikan kepastian batas terluar landas kontinen. Demikian juga pengertian landas kontinen selain mencakup pengertian yuridis juga mencakup pengertian geologis yang merupakan penyempurnaan dari pengertian landas kontinen itu sendiri. Perumusan yang terdapat dalam Konvensi Hukum Laut 1982, selain merupakan penyempurnaan dari pengertian landas kontinen yang dapat dianggap sebagai perkembangan hukum laut masa kini, perumusan tersebut dapat menimbulkan kekaburan atau ketidak jelasan dalam menafsirkan pengertian "continental shelf". Hal ini bisa dilihat dari alternatif-alternatif yang digunakan untuk menentukan batas terluar landas kontinen sampai pinggiran luar tepian kontinen atau melampaui batas itu, sesungguhnya cara pengukuran ini sudah jauh meninggalkan pengertian "continental shelf" dalam arti geologis semata-mata.

Adapun cara penetapan Penentuan batas terluar dari landas kontinen yang dinyatakan dalam UNCLOS 1982 adalah sebagai berikut: ${ }^{16}$

a. Didasarkan pada titik tetap terluar dimana ketebalan batu endapan (sedimentary rock) paling sedikit sebesar $1 \%$ dari jarak terdekat antara titik tersebut dengan kaki lereng kontinen.

\footnotetext{
${ }^{16}$ Wahyudi Tapawira, Jurnal 2013, Cara Penetapan Landas Kontinen Menurut United Nation Convention On The Law Of The Sea 1982 (Unclos 1982) Di Laut Cina Selatan Terhadap Cina, Taiwan, Filipina, Malaysia, Brunai Darusalam, Indonesia Dan Vietnam, UAJ Yogyakarta, hlm.8.
} 
b. Jarak 60 mil laut dari kaki lereng kontinen.

c. Batas terluar dari landas kontinen tidak boleh melebihi 350 mil laut dari garis pangkal dimana batas teritorial diukur.

d. Batas terluar dari Landas Kontinen tidak melebihi 100 mil laut dari garis kedalaman $2500 \mathrm{~m}$.

Secara geofisik dasar laut yang berbatasan dengan pantainya umumnya terdiri dari 3 bagian yang terpisah, yaitu "continental shelf", "continental slope” dan "continental rise", yang secara keseluruhan disebut "continental margin" atau tepian kontinen. Sedangkan "continental shelf" bukan merupakan keseluruhan dari "continental margin". Sehingga penggunaan istilah "continental shelf" sudah tidak relevan lagi dan dapat menimbulkan kekaburan atau ketidak jelasan pengertian dari "continental shelf", karena sudah mencapaui batas terluar "continental margin" atau dapat juga melampaui batas itu. Kalau dalam bahasa Indonesia dibedakan pengertian dan istilah dari "continental shelf” dalam arti geologis, yaitu dengan sebutan dataran kontinen, dan "continental shelf" dalam arti yuridis yang disebut landas kontinen, kiranya perlu juga dipikirkan oleh ahli hukum laut internasional untuk memberikan istilah yang lebih tepat untuk "continental shelf" dalam arti yuridis sehingga tidak menimbulkan kekaburan pengertian "continental shelf" tersebut.

\subsection{Pengaturan Nasional}

Dalam rangka menjamin kepastian hukum serta dasar bagi pelaksanaan hak-hak eksploitasidi landas kontinen Indonesia, pada tanggal 6 Januari 1973 Pemerintah mengukuhkan Undang-Undang Nomor 1 Tahun 1973 tentang Landas Kontinen Indonesia. Undang-undang ini terdiri atas 14 pasal dengan sistematika sebagai berikut :

a. BAB I mengenai ketentuan umum (Pasal 1)

b. BAB I mengenai status kekayaan di landas kontinen (Pasal 2 dan Pasal 3)

C. BAB I mengenai eksplorasi, eksploitasi dan penyelidikan ilmiah (Pasal 4 dan Pasal 5)

d. BAB I mengenai intalasi (Pasal 6 dan Pasal 7)

e. BAB I mengenai pencemaran (Pasal 8)

f. BAB I mengenai yuridiksi negara (Pasal 9)

g. BAB I mengenai perlindunga terhadap kepentingan-kepentingan lain (Pasal 10)

h. BAB I mengenai ketentuan-ketentuan pidana (Pasal 11 dan Pasal 12) 
i. BAB I mengenai ketentuan penutup (Pasal 13 dan Pasal 14)

Dengan ketentuan diatas maka negara Indonesia yang merupakan salah satu negara yang telah meratifikasi UNCLOS harus mematuhi setiap ketentuan yang telah diatur oleh UNCLOS dan dengan diratifikasi UNCLOS 1982 maka Indonesia mengeluarkan UndangUndang Nomor 17 Tahun 1985.

\subsection{Pengaturan Internasional}

Menurut Pasal 55 UNCLOS (United Nations Convention on the Law Of the Sea) 1982, ZEE adalah suatu daerah tambahan diluar dan berdampingan dengan laut teritorial, yang tunduk pada khusus yang ditetapkan dalam bab ini berdasarkan mana hak-hak dan yurisdiksi negara pantai dan hak-hak serta kebebasan-kebebasan negara lain, diatur oleh ketentuanketentuan yang lebih relevan.

Zona Ekonomi Eksklusif dalam UNCLOS 1982 diatur dalam BAB V mengenai Zona Ekonomi Eksklusif tepatnya pada Pasal 55 sampai Pasal 75. Adapun rincian pasal ZEE di UNCLOS adalah: a) Pasal 56 mengenai hak-hak, yurisdiksi dan kewajiban Negara pantai dalam zona ekonomi eksklusif. b) Pasal 58 mengenai hak-hak dan kewajiban negara lain di zona ekonomi eksklusif. c) Pasal 69 mengenai hak-hak negara yang tak berpantai. d) Pasal 70 hak negara yang secara geografis tak beruntung. e) Pasal 73 mengenai penegakan peraturan perundang-undangan negara pantai. f) Penetapan batas zona ekonomi eksklusif antara Negara yang pantainya berhadapan atau berdampingan.

1. Penetapan batas zona ekonomi eksklusif antara Negara yang pantainya berhadapan atau berdampingan harus diadakan dengan persetujuan atas dasar hukum internasional, sebagaimana ditetapkan dalam Pasal 38 Status Mahkamah Internasional, untuk mencapai suatu pemecahan yang adil.

2. Apabila tidak dapat dicapai persetujuan dalam jangka waktu yang pantas, Negaranegara yang bersangkutan harus menggunakan prosedur yang ditentukan dalam Bab XV.

3. Sambil menunggu suatu persetujuan sebagaimana ditentukan dalam ayat 1 , Negaranegara yang bersangkutan, dengan semangat saling pengertian dan kerjasama, harus melakukan setiap usaha untuk mengadakan pengaturan sementara yang bersifat praktis dan, selama masa peralihan ini, tidak membahayakan atau menghalangi 
dicapainya suatu persetujuan akhir. Pengaturan demikian tidak boleh merugikan bagi tercapainya penetapan akhir mengenai perbatasan.

4. Dalam hal adanya suatu persetujuan yang berlaku antara negara-negara yang bersangkutan, maka masalah yang bertalian dengan Penetapan batas Zona Ekonomi Eksklusif harus ditetapkan sesuai dengan ketentuan persetujuan itu.

Prinsip hukum delimitasi ZEE diatur dalam Pasal 74 konvensi hukum laut 1982. Rumusan pasal ini secara mutatis mutandis sama dengan Pasal 83 tentang delimitasi landas kontinen. Pasal 75 mengenai peta dan daftar koordinat geografis.

\subsection{Pengaturan Nasional}

Menurut Undang-Undang Nomor 5 Tahun 1983 tentang ZEE Indonesia, Pasal 2 ZEE adalah jalur di luar dan berbatasan dengan laut wilayah Indonesia sebagaimana ditetapkan berdasarkan undang-undang yang berlaku tentang perairan Indonesia yang meliputi dasar laut, tanah di bawahnya dan air di atasnya dengan batas terluar 200 Mil laut (nm) diukur dari garis pangkal laut wiayah Indonesia. Berpijak pada konsepsi yang tetapkan oleh hukum Indonesia batasan ZEE indonesia adalah air/laut yang berada diatas ZEE Indonesia dan daerah dibawahnya mulai dari luar laut wilayah sampai jarak 200 Mil.

ZEEI adalah wilayah perikanan Indonesia, ZEEI meliputi dasar laut, tanah di bawahnya dan air diatanya dengan batas terluar 200 mil laut dari garis pangkal. Di ZEEI, Indonesia mempunyai hak berdaulat atas pengelolaan dan konservasi SDA hayati, orang atau badan hukum asing dapat melakukan penangkapan ikan di ZEEI dengan perjanjian dengan Pemerintah Indonesia. Penegakan hukum dilakukan dengan pidana denda dan atau pidana penjara bila diperjanjikan. Hal ini diatur dalam Bab III Pasal 4 Undang-Undang Nomor 5 Tahun 1983 tentang Zona Ekonomi Eksklusif Indonesia. Di Zona Ekonomi Eksklusif Indonesia, Republik Indonesia mempunyai hak dan dapat melaksanakan:

1) Hak berdaulat untuk melakukan eksplorasi dan eksploitasi, pengelolaan dan konservasi sumber daya alam hayati dan non hayati dari dasar laut dan tanah di bawahnya serta air di atasnya dan kegiatan-kegiatan lainnya untuk eksplorasi dan eksploitasi ekonomis zona tersebut, seperti pembangkitan tenaga dari air, arus dan angin.

2) Yurisdiksi yang berhubungan dengan: a) Pembuatan dan penggunaan pulau-pulau buatan, instalasi-instalasi dan bangunan-bangunan lainnya, b) Penelitian ilmiah 
mengenai kelautan, c) Perlindungan dan pelestarian lingkungan laut, d) Hak-hak lain dan kewajiban-kewajiban lainnya berdasarkan Konvensi Hukum Laut yang berlaku.

Sepanjang yang bertalian dengan dasar laut dan tanah di bawahnya, hak berdaulat, hakhak lain, yurisdiksi dan kewajiban-kewajiban Indonesia sebagaimana dimaksud dalam ayat (1) dilaksanakan menurut peraturan perundang-undangan Landas Kontinen Indonesia, persetujuan-persetujuan antara Republik Indonesia dengan negara-negara tetangga dan ketentuan-ketentuan hukum internasional yang berlaku. Di Zona Ekonomi Eksklusif Indonesia, kebebasan pelayaran dan penerbangan Internasional serta kebebasan pemasangan kabel dan pipa bawah laut diakui sesuai dengan prinsip-prinsip hukum laut Internasional yang berlaku.

Sesuai dengan prinsip-prinsip hukum internasional yang berlaku seperti yang tumbuh dari praktek negara dan dituangkan dalam Konvensi Perserikatan Bangsa Bangsa tentang Hukum Laut yang dihasilkan oleh Konferensi Perserikatan Bangsa Bangsa tentang Hukum Laut Ketiga di zona ekonomi eksklusif setiap negara, baik negara pantai maupun negara tak berpantai, menikmati kebebasan pelayaran dan penerbangan Internasional serta kebebasan pemasangan kabel dan pipa bawah laut, serta penggunaan laut yang bertalian dengan kebebasan-kebebasan tersebut seperti pengoperasian kapal-kapal, pesawat udara dan pemeliharaan kabel dan pipa bawah laut.

ZEE di Indonesia diatur atau dimuat dalam perturan-peraturan sebagai berikut: a) Pengumuman ZEEI: 21 Maret 1980, b) UU No.5 Tahun 1983 (L.N. Tahun 1985 No.44) tentang ZEE Indonesia, c) UU Nomor 31 tahun 2004 jo UU no 545 Tahun 2009 tentang Perikanan, d) UU No.5 Tahun 1990 (L.N. 1990 No.49) tentang Konservasi sumber daya alam hayati dan ekosistemnya, e) PP Nomor 52 Tahun 2002 tentang Usaha Perikanan, f) PP nomor 60 Tahun 2007 tentang Konservasi Sumber Daya Ikan, g) Peraturan Menteri Kelautan dan Perikanan Nomor 5 Tahun 2008 yang diperbarui dengan Peraturan Menteri Kelautan dan Perikanan Nomor 9 Tahun 2009 tentang Usaha Perikanan Tangkap, h) Peraturan Menteri Kelautan dan Perikanan Nomor ; PER.01/MEN 2009 tentang Wilayah Pengelolaan Perikanan Republik Indonesia, i) KEP.60/MEN/2001 Penataan Penggunaan Kapal Perikanan Di Zona Ekonomi Eksklusif Indonesia, dan j) KEP.06/MEN/2010 Alat Penangkapan Ikan Di Wilayah Pengelolaan Perikanan Negara Republik Indonesia. 


\subsection{Analisis Perjanjian Negara Indonesia dan Malaysia Dalam Pembagian Wilayah ZEE dan Landas Kontinen Di Selat Malaka}

\subsubsection{Perjanjian Indonesia dan Malaysia mengenai landas kontinen}

Indonesia dan Malaysia telah mengadakan perjanjian bilateral terkait penetapan landas kontinen setiap negara. perjanjian dengan berdasarkan kesepakatan anatara Indonesia dan Malaysia telah diadakan pada Tahun 1969 dan terdiri dari 7 pasal, setiap pasal menerangkan dan menjelaskan spesifikasi penetapan dalam pembagian landas kontinen.

Pada Pasal 1 telah ditetapkan titik-titik koordinat landas kontinen antara Indonesia dan Malaysia. Adapun titik koordinat landas kontinen yang disepakati di selat Malaka adalah:

Tabel 3.5.1

Titik Kordinat Landasan Kontinen

\begin{tabular}{|c|c|c|}
\hline 1 & 2 & 3 \\
\hline Nomor titik & Garis bujur timur & Garis lintang utara \\
\hline 1 & $98^{\circ} 17^{\prime} .5$ & $05^{\circ} 27^{\prime} .0$ \\
\hline 2 & $98^{\circ} 41^{\prime} .5$ & $04^{\circ} 55^{\prime} .7$ \\
\hline 3 & $99^{\circ} 43^{\prime} .6$ & $03^{\circ} 59^{\prime} .6$ \\
\hline 4 & $99^{\circ} 55^{\prime} .0$ & $03^{\circ} 47^{\prime} .4$ \\
\hline 5 & $101^{\circ} 12^{\prime} .1$ & $02^{\circ} 41^{\prime} .5$ \\
\hline 6 & $101^{\circ} 46^{\prime} .5$ & $02^{\circ} 15^{\prime} .4$ \\
\hline 7 & $102^{\circ} 13^{\prime} .4$ & $01^{\circ} 55^{\prime} .2$ \\
\hline 8 & $102^{\circ} 35^{\prime} .0$ & $01^{\circ} 41^{\prime} .2$ \\
\hline 9 & $103^{\circ} 13^{\prime} .9$ & $01^{\circ} 19^{\prime} .5$ \\
\hline 10 & $103^{\circ} 22^{\prime} .8$ & $01^{\circ} 15^{\prime} .0$ \\
\hline
\end{tabular}

Dari tabel di atas maka dapat kita lihat bahwa ada ketentuan/ketetapan yang tidak boleh dilanggar oleh kedua negara. Ketetapan pembagian wilayah di atas telah disetuji dan diakui oleh kedua negara dengan itikad baik dalam menjalankan kesepakatan antara Indonesia dan Malaysia. Untuk melihat lokasi perbatasan secara konkrit hasil dari kesepakatan itu adalah dengan disepakati juga pembentukan peta yang nantinya akan menjadi lampiran A dari kesepakatan/perjanjian ini. Adapun dalam menentukan letak secara konkrit dari setiap 
koordinat diatas akan dibentuk dan disepakati oleh pejabat yang berwenang untuk hal itu, sesuai dengan ayat (3) dari pasal 1 dalam perjanjian ini.

Pada Pasal 2 bahwa setiap negara menjamin akan menjadikan perjanjian ini hukum disetiap negara yang harus dan wajib dipatuhi oleh negara dan rakyat setiap negara. Untuk menjadikan perjanjian ini sebagai ketentuan hukum, maka kedua negara harus melakukan legalitas hukum terhadap perjanjian ini, apakah dibentuk undang-undang ataupun peraturan lainnya yang dapat menjadikan perjanjian/kesepakatan ini sebagai dasar hukum positif. Pada Pasal 3 menjelaskan bahwa perjanjian ini tidak akan mempengaruhi perjanjian dimasa akan datang, artinya ketika setiap negara menginginkan perubahan perjanjian untuk mengikuti perkembangan zaman maka hal itu bisa dilakukan dengan syarat apabila perjanjian yang akan datang belum disahkan secara legalitas hukum, maka perjanjanjian yang berlaku adalah kesepakatan awal dari perjanjian awal.

Pada Pasal 4 dijelaskan bahwa dalam melakukan eksploitasi di daerah landas kontinen harus dilakukan dengan baik-baik tanpa melanggar ketentuan-ketentuan berlaku, dan untuk cara melaksanakan eksploitasi itu dapat didiskusikan oleh kedua neagara. Pada Pasal 5 menerangkan tentang ketika terjadinya konflik dikemudian hari yang diakibatkan oleh perjanjian ini maka kedua negara harus menyelesaikan persoalan secara damai untuk kemaslahatan bersama, seperti dengan cara musyawarah, mediasi dan cara-cara dami lainnya. Pasal 6 pada perjanjian ini mempertegas kembali dari Pasal 2 bahwa perjanjian ini akan dilakukan legalitas hukum di setiap negara. Pada pasal terakhir menjelaskan terkait bahwa perjanjian/kesepakatan ini berlaku setelah perjanjian ini ditandatangani.

Perjanjian yang dibuat oleh Indonesia dan Malaysia terkait pembagian landas kontinen ditulis dengan 3 bahasa yaitu bahasa Indonesia, bahasa Malaysia dan bahasa Inggris. Hal ini dilakukan untuk menjadi solusi dikemudian hari yang hal ini dapat menjadi solusi dari persolan yang apabila muncul dikemudian hari. Perjanjian ini ditandatangani oleh perwakilan setiap negara (Indonesia dan Malaysia). Indonesia diwakilkan oleh Prof. Dr. Ir. Soemantri Brodjonegoro sedangkan dari pihak Malaysia di wakilkan oleh Tan Ari Abdul Kadir bin Yusof.

Penentuan titik koordinat tersebut ditetapkan berdasarkan Garis Pangkal masingmasing negara. Dengan diberlakukannya Konvensi Hukum Laut Internasional 1982, maka penentuan titik dasar dan garis pangkal dari tiap-tiap negara perlu diratifikasi berdasarkan aturan badan Internasional yang baru. Selama ini penarikan batas Landas Kontinen Indonesia dengan Malaysia di Perairan Selat Malaka berpedoman pada Konvensi Hukum Laut 1958. 
MoU RI dengan Malaysia yang ditandatangani pada 27 Oktober 1969 yang menetapkan Pulau Jara dan Pulau Perak sebagai acuan titik dasar dalam penarikan Garis Pangkal jelas merugikan pihak Indonesia, karena median line yang diambil dalam menentukan batas landas kontinen kedua negara tersebut cenderung mengarah ke perairan Indonesia. Tidak hanya itu, Indonesia juga belum ada kesepakatan dengan pihak Malaysia tentang ZEE-nya.

Penentuan ZEE ini sangat penting dalam upaya pengelolaan sumberdaya perikanan masing-masing negara. Akibat belum adanya kesepakatan ZEE antara Indonesia dengan Malaysia di Selat Malaka, sering terjadi penangkapan nelayan oleh kedua belah pihak. Hal ini disebabkan karena Malaysia menganggap batas Landas Kontinennya di Selat Malaka, sekaligus merupakan batas laut dengan Indonesia. Hal ini tidak benar, karena batas laut kedua negara harus ditentukan berdasarkan perjanjian bilateral. Berdasarkan kajian Dinas HidroOseanografi TNI AL, batas laut Indonesia dan Malaysia di Selat Malaka seharusnya berada di median line antara garis pangkal kedua negara yang letaknya jauh di sebelah utara atau timur laut batas Landas Kontinen.

Berdasarkan ketentuan UNCLOS-82, sebagai coastal state, Malaysia tidak diperbolehkan menggunakan Pulau Jara dan Pulau Perak sebagai base line yang jarak antara kedua pulau tersebut lebih dari 100 mil laut. Jika ditinjau dari segi geografis, daerah yang memungkinkan rawan sengketa perbatasan dalam pengelolaan sumber-sumber perikanan adalah di bagian selatan Laut Andaman atau di bagian utara Selat Malaka.

\subsubsection{Delimitasi ZEE di Selat Malaka}

Belum disepakatinya batas ZEE di Selat Malaka antara Indonesia dan Malaysia menjadikan kedua negara masing-masing memiliki klaim unilateral untuk batas ZEE. Berdasarkan Peta Negara Kesatuan Republik Indonesia (NKRI) yang diterbitkan oleh Badan Informasi Geospasial (BIG), Indonesia memiliki klaim ZEE yang berbeda dengan Malaysia. Forward position Indonesia untuk batas ZEE antara kedua negara tidak berimpit dengan garis landas kontinen lebih ke utara dari batas landas kontinen yang disepakati sebelumnya. ${ }^{17}$ Malaysia mengklaim batas ZEE yang berimpit dengan batas landas kontinen dengan Indonesia yang sudah disepakati sebelumnya. Klaim unilateral Malaysia, sebagai forward position batas ZEE Malaysia tersebut ditampilkan pada Peta Baru Malaysia yang diterbitkan tahun 1979. Belum disepakatinya ZEE antara Indonesia dan Malaysia memberi dampak yang

\footnotetext{
${ }^{17}$ Farid, Yuniar., 2014, Tesis Magister, Kajian Teknis Delimitasi Batas Zona Ekonomi Eksklusif Antara Indonesia Dan Malaysia Di Selat Malaka, Program Pascasarjana Fakultas Teknik Universitas Gadjah Mada, hlm.3
} 
kurang baik pada hubungan kedua negara, antara lain ditandai dengan terjadinya insideninsiden di wilayah perbatasan.

Pada tanggal 7 April 2011 terjadi insiden yang melibatkan kapal berbendera Malaysia, Kapal Hiu 001 dari Kementerian Kelautan dan Perikanan (KKP) Indonesia, dan tiga helikopter Malaysia yang terdiri dari dua helikopter Maritim Malaysia dan satu buah helikopter tempur Tentara Laut Diraja Malaysia (TLDM) Malaysia yang bersenjata lengkap. Pada insiden tersebut patroli Indonesia menangkap kapal Malaysia yang dianggap memasuki perairan ZEE Indonesia secara ilegal. Setelah penangkapan nelayan oleh petugas KKP, tiga helikopter Malaysia muncul dan meminta kapal Malaysia tersebut dilepaskan. Petugas KKP Indonesia menolak dan kapal tetap dibawa ke Pelabuhan Belawan. Dengan belum disepakatinya batas ZEE antara Indonesia dan Malaysia berpotensi terus menimbulkan insiden-insiden di kemudian hari. ${ }^{18}$

Metode Three Stage Approach yang pertama kali digunakan oleh Mahkamah Internasional tahun 2009 untuk sengketa Rumania dan Ukraina, dapat digunakan untuk delimitasi batas ZEE antara Indonesia dan Malaysia di Selat Malaka. Dengan metode tersebut, ditentukan pantai relevan dan area relevan, dimana panjang pantai relevan untuk Indonesia sepanjang $438 \mathrm{~km}$ yang menghubungkan TD.181A sampai dengan TD.185, dan untuk Malaysia sepanjang $431 \mathrm{~km}$ dengan menghubungkan beberapa pulau terluar Malaysia. Sedangkan area maritim yang dilakukan proses delimitasi seluas $70.722 \mathrm{~km} .{ }^{19}$

Proses delimitasi ZEE dilakukan dengan menggunakan garis pangkal kepulauan untuk Indonesia yaitu dari TD.181A sampai dengan TD.185, dan Malaysia dapat menggunakan garis pangkal normal dengan melibatkan beberapa pulau terluar Malaysia, yaitu di sekitar Kepulauan Sembilan, Pulau Pangkor, Pulau Kendi, dan Pulau Langkawi. Selain garis pangkal normal, Malaysia dapat menggunakan garis pangkal lurus dengan menghubungkan pulaupulau terluar dan tidak menggunakan daratan utama dalam konfigurasi garis pangkal tersebut. Dua fitur maritim yang menjadi isu penting dalam delimitasi batas ZEE di Selat Malaka adalah Pulau Jarak dan Pulau Perak. Pulau Jarak terletak lebih dari 27 mil laut dan Pulau Perak terletak lebih dari 86 mil laut masing-masing dari daratan utama Malaysia yang terdekat. Berdasarkan yurisprudensi delimitasi ZEE dan landas kontinen oleh Mahkamah Internasional tentang peran pulau kecil pada delimitasi maritim, kedua fitur maritim tersebut tidak dapat dijadikan sebagai titik pangkal Malaysia.

\footnotetext{
${ }^{18} \mathrm{lbid}, \mathrm{hlm} .5$.

${ }^{19} \mathrm{Ibid}, \mathrm{hlm} .83$.
} 
Hal ini karena dengan menggunakan dua pulau tersebut sebagai titik pangkal, maka tidak sesuai dengan bentuk konfigurasi umum dari daratan utama Malaysia. Pada tahapan delimitasi, kedua pulau dapat diperhitungkan sebagai relevant circumstances. Pada yurisprudensi penyelesaian sengketa batas ZEE oleh Mahkamah Internasional, pulau kecil dapat diberi bobot nol (nil effect). Jika diberikan bobot nol untuk Pulau Jarak dan Pulau Perak, maka yang memberi perubahan pada garis ekuidistan yang terbentuk adalah Pulau Jarak karena terletak kurang dari 12 mil laut dari garis ekuidistan. Sedangkan Pulau Perak tidak memberikan dampak signifikan terhadap perubahan garis ekuidistan. Jika Pulau Jarak dan Pulau Perak digunakan dalam delimitasi sebagai titik pangkal, terdapat dua kemungkinan konfigurasi, yaitu kedua pulau dihubungkan dan sebagai garis pangkal lurus, atau masingmasing sebagai titik pangkal. Penggunaan kedua pulau sebagai titik pangkal memberikan perubahan signifikan pada hasil delimitasi. Namun demikian, hal tersebut tidak sesuai dengan aturan-aturan yang ada di UNCLOS dan yurisprudensi terutama peran pulau kecil dalam delimitasi batas maritim.

Luas yang diperoleh masing-masing negara jika delimitasi dilakukan dengan opsi pertama, dimana Indonesia menggunakan garis pangkal kepulauan dan Malaysia menggunakan garis pangkal normal adalah Indonesia mendapatkan $38.577 \mathrm{~km}$ dan Malaysia mendapatkan $32.200 \mathrm{~km}^{2}$. Dengan opsi kedua, dimana Indonesia menggunakan garis pangkal kepulauan dan Malaysia menggunakan garis pangkal lurus, luas ZEE yang diperoleh Indonesia adalah $36.826 \mathrm{~km}^{2}$, sedangkan luas ZEE Malaysia sebesar $33.896 \mathrm{~km}^{2}$. Uji disproporsionalitas yang dilakukan dengan membandingkan panjang pantai relevan masingmasing negara menghasilkan perbandingan 1,06 : 1 lebih panjang Indonesia. Perbandingan luas ZEE yang diterima pada opsi pertama menghasilkan perbandingan 1,198 : 1, dan opsi kedua menghasilkan perbandingan 1,086 : 1. Dengan mendasarkan kepada yurisprudensi penyelesaian sengketa batas ZEE dan landas kontinen oleh Mahkamah Internasional dan ITLOS, maka tidak perlu dilakukan perubahan garis ekuidistan yang sudah dihasilkan pada proses delimitasi. $^{20}$

Seperti halnya batas landas kontinen yang dilengkapi dengan common point antara Indonesia, Malaysia, dan Thailand, batas ZEE pada wilayah perairan yang melibatkan ketiga negara membutuhkan common point. Dari hasil penelitian common point landas kontinen terletak lebih dari 24 mil laut dari garis ekudistan ZEE. Indonesia dan Malaysia sehingga

${ }^{20} \mathrm{Ibid}, \mathrm{hlm} .84$. 
kecil kemungkinan dapat digunakan juga untuk batas ZEE. Dengan potensi hasil delimitasi ZEE yang tidak segaris dengan garis landas kontinen yang sudah disepakati Indonesia dan Malaysia, maka beberapa potensi utamanya pada kewenangan eksplorasi dan eksploitasi wilayah maritim akan menjadi tantangan. Kedua negara dapat mengatur hal tersebut bersama dengan perjanjian batas ZEE nantinya jika disepakati dengan mengatur secara detil kewenangan masing-masing negara dengan mendasarkan pada hukum laut Internasional.

\section{SIMPULAN DAN SARAN}

\subsection{Simpulan}

Indonesia dan Malaysia memiliki sejarah panjang mengenai kelautan, mulai dari laut teritorial, zona tambahan hingga Zona Ekonomi Eklusif (ZEE). Dengan sejarah panjang tersebut maka mengakibatkan konflik disetiap negara dalam menentukan perbatasan wilayah laut, terutama wilayah landas kontinen dan ZEE yang merupakan sumber pertikaian dalam mempertahankan kedaulatan laut negara. Setiap negara akan mempertahankan wilayah kedaulatannya dengan berbagai cara dan metode karena dalam melakukan penetapan ukuran landas kontinen akan sangat berpengaruh terhadap memaksimalkan jumlah pemanfaatan sumder daya alam yang berada di laut oleh negara. Indonesia dan Malaysia telah melakukan perjanjian mengenai landas kontinen pada tahun 1969 yang masih berlaku sampai saat sekarang ini. Dalam melakukan penetapan pengukuran landas kontinen cukup merugikan Indonesia dari aspek tolak ukur dimulainya pengukuran.

\subsection{Saran}

Perjanjian yang dilakukan oleh Indonesia dan Malaysia dalam menentukan wilayah landas kontinen dan wilayah ZEE masih kurang maksimal, hal ini dibuktikan dengan perjanjian lama yang belum dilakukan perubahan dan perkembangan, seperti perjanjian/kesepakatan penetapan landas kontinen yang dilakukan pada tahun 1969 dan masih digunakan hingga saat sekarang ini. Begitupun perjanjian dalam menentukan batas wilayah ZEE Indonesia dan Malaysia yang belum pernah dilakukan perjanjian secara khusus oleh dua negara tersebut hingga sampai saat ini. Dengan tidak ada nya dilakukan perjanjian secara khusus dan melakukan pembaharuan perjanjian mengenai penentuan batas wilayah ZEE dan landas kontinen maka akan berpotensi menimbulkan konflik di laut wilaya ZEE dan landas kontinen tersebut. 


\section{DAFTAR PUSTAKA}

\section{Literatur}

Annisa Purwatiningsih, "Eksplorasi dan Eksploitasi Pertambangan Minyak dan Gas Bumi di Laut Natuna Bagian Utara Laut Yuridiksi Nasional Untuk Meningkatkan Kesejahteraan Masyarakat di Kepulauan Natuna", Jurnal Reformasi, Volume 2, Nomor 2, Juli-Desember 2012.

Ansori, "Cara Penetapan Batas Zee Antara Indonesia Dan Malaysia Diselat Malaka Dengan Media Line", Jurnal Perspektif Hukum, Vol. 12 No. 2 November 2012.

Farid Yuniar, "Kajian Teknis Delimitasi Batas Zona Ekonomi Eksklusif Antara Indonesia Dan Malaysia Di Selat Malaka", Tesis Magister, Yogyakarta: Program Pascasarjana Fakultas Teknik Universitas Gadjah Mada, 2014.

Hans Dieter Evers, dan Solvay Gerke, Perkembangan Dan Peluang Wilayah Selat Malaka, Center For Development Research University Of Bonn.

Irianto Sulistyowati, dan Sidharta, Metode Penelitian Hukum: Kontelasi dan Refleksi, Jakarta: Yayasan Pustaka Obor Indonesia, 2011.

I Wayan Parthiana, Hukum Laut Internasional dan Hukum Laut Indonesia, Bandung: Yrama Widya, 2014.

Peter Mahmud Marzuki, Penelitian Hukum, Edisi revisi, Jakarta: Kencana, 2013.

Suparman A Diraputra, Naskah Akademik Rancangan Undang-Undang Tentang Perubahan Undang-Undang Nomor 1 Tahun 1973 Tentang Landas Kontinen Indonesia, Badan Pembinaan Hukum Nasional Kementerian Hukum dan Hak Asasi Manusia Republik Indonesia, 2012.

Zainuddin Ali, Metode Penelitian Hukum, Jakarta: Sinar Grafika, 2010.

http://lawfile.blogspot.co.id/2012/01/sejarah-singkat-perkembangan-landas. html, diakses tanggal 12 Mei 2019.

https://id.wikipedia.org/wiki/Selat_Malaka, Sejarah Selat Malaka, diakses tanggal 12 Mei 2019.

http://repository.umy.ac.id/bitstream/handle/123456789/2629/BAB\%20II.pdf?sequence=6\&i sAllo wed=y, diakses tanggal 12 Mei 2019.

Konvensi Hukum Laut 1982

Ordonansi Hindia Belanda Staatsblad 1939 Nomor 442

Undang-Undang Dasar Republik Indonesia 1945

Undang-Undang Nomor 1 Tahun 1973 tentang Landas Kontinen Indonesia Undang-Undang Nomor 5 Tahun 1983 tentang Zona Ekonomi Eksekutif Indonesia

United Nation Convention On The Law Of Sea (UNCLOS) 1982. 